\title{
Low level of the immune response against rabies virus in dogs and cats, a cross-sectional study in sheltered animals, Santander, Colombia ${ }^{1}$
}

\author{
Lina María Trujillo-Rojas², Marlén Martínez-Gutierrez ${ }^{3,4}$ and Julian Ruiz-Saenz ${ }^{4 *}$
}

\begin{abstract}
Trujillo-Rojas L.M., Gutierrez-Gutiérrez M. \& Ruiz-Saenz J. 2018. Low level of the immune response against rabies virus in dogs and cats, a cross-sectional study in sheltered animals, Santander, Colombia. Pesquisa Veterinária Brasileira 38(11):2109-2116. Universidad Cooperativa de Colombia, Bucaramanga, Colombia. E-mail: julianruizsaenz@gmail.com, julian.ruizs@campusucc.edu.co

Rabies is an incurable and fatal progressive viral encephalomyelitis that causes approximately 61,000 deaths a year globally mainly by dog bites, which show the importance of anti-rabies vaccination in dogs to achieve elimination of the disease. In Colombia, multiple cases of human rabies transmitted by dogs and cats have been reported since 1999, showing an increased significance of cats in the transmission of rabies, mainly in rabies of wild origin. Therefore, the aim of the present study was to evaluate the development of neutralizing antibodies in dogs and cats during the mass vaccination campaign of the second half of 2015 in the city of Bucaramanga. For this purpose, a descriptive cross-sectional study with convenience sampling was conducted in 382 dogs and cats ( 295 dogs, 87 cats), and an evaluation of the humoral immune response of the animals was performed by quantitative ELISA. The prevalence of optimal neutralizing antibodies $(>0.5 \mathrm{IU} / \mathrm{ml})$ was only $32.76 \%(95 \% \mathrm{CI}=28.05-37.46 \%)$ in the entire population studied and most of the animals did not have an adequate response to the vaccination, or seroconversion was not detected on them $(65.45-95 \%$ confidence interval, $\mathrm{CI}=60.68-70.21 \%$ ). Significant difference was found between the neutralizing antibody titers in cats and dogs, with a higher neutralizing response in cats. In conclusion, although mass vaccination campaigns for dogs and cats are the most important measure to interrupt virus circulation among the animals, achievement of a good neutralizing immune response in the animals is useful to demonstrate that vaccination has been successful, allowing the maintenance of the required minimum levels of population immunity. These results will allow the implementation of corrective measures in Bucaramanga to achieve better seroconversion rates. Other cities are expected to implement similar seroconversion assessments to verify the quality of effective anti-rabies vaccination in animal populations.
\end{abstract}

INDEX TERMS: Immune response, rabies virus, dogs, cats, sheltered animals, Santander, Colombia, vaccination.

RESUMO.- [Baixo nível de resposta imune contra o vírus da raiva em cães e gatos, um estudo transversal em animais abrigados, Santander, Colombia.] A raiva é uma encefalomielite

\footnotetext{
${ }^{1}$ Received on July 19, 2018.

Accepted for publication on July 25, 2018.

${ }^{2}$ Universitad Autònoma de Barcelona, Barcelona, España.

${ }^{3}$ Infettare, Facultad de Medicina, Universidad Cooperativa de Colombia, Medellín, Colombia.

${ }^{4}$ Grupo de Investigación en Ciencias Animales (GRICA), Universidad Cooperativa de Colombia, Calle 30A \# 33-51, Bucaramanga, Colombia. *Corresponding author: julianruizsaenz@gmail.com, julian.ruizs@campusucc.edu.co; Phone: +57-7-685 4500 ext 7037 .
}

viral progressiva incurável e fatal que causa aproximadamente 61.000 mortes por ano no mundo, principalmente por mordidas de cães, que mostram a importância da vacinação anti-rábica em cães para conseguir a eliminação da doença. Na Colômbia, vários casos de raiva humana transmitida por cães e gatos foram relatados desde 1999, mostrando um aumento na importância de gatos na transmissão da raiva, principalmente em raiva de origem selvagem. Portanto, o objetivo do presente estudo foi avaliar o desenvolvimento de anticorpos neutralizantes em cães e gatos durante a campanha de vacinação em massa do segundo semestre de 2015 na cidade de Bucaramanga. Para este propósito, um estudo descritivo 
transversal com amostragem de conveniência foi realizado em 382 cães e gatos (295 cães, 87 gatos), e uma avaliação da resposta imune humoral dos animais foi realizada por ELISA quantitativo. A prevalência de anticorpos neutralizantes ótimos $(>0,5 \mathrm{UI} / \mathrm{ml}$ ) foi de apenas 32,76\% (IC 95\%= 28,05-37,46\%) em toda a população estudada e a maioria dos animais não teve resposta adequada à vacinação, ou a soroconversão foi não detectado neles $(65,45-95 \%$ intervalo de confiança IC = 60,68-70,21\%). Diferença significativa foi encontrada entre os títulos de anticorpos neutralizantes em gatos e cães, com uma maior resposta neutralizante em gatos. Em conclusão, embora as campanhas de vacinação em massa para cães e gatos sejam a medida mais importante para interromper a circulação do vírus entre os animais, a obtenção de uma boa resposta imunológica neutralizante nos animais é útil para demonstrar que a vacinação foi bem sucedida, permitindo a manutenção necessária dos níveis mínimos de imunidade da população. Esses resultados permitirão que a implementação de medidas corretivas em Bucaramanga alcance melhores taxas de soroconversão. Outras cidades devem implementar avaliações similares de soroconversão para verificar a qualidade da vacinação anti-rábica efetiva em populações animais.

TERMOS DE INDEXAÇÃO: Resposta imune, vírus da raiva, caninos, felinos, animais abrigados, Santander, Colombia, vacinação.

\section{INTRODUCTION}

Rabies is an incurable and fatal progressive viral encephalomyelitis caused by a lyssavirus (Bourhy et al. 2008). Rabies virus (RABV) belongs to the order Mononegavirales, family Rhabdoviridae, and genus Lyssavirus (Afonso et al. 2016). Rabies transmission occurs in two epidemiological forms: a) urban, with the dog as the main reservoir and transmitter, and b) wild, with animals such as bats, foxes, and wolves as reservoirs and transmitters and cats as transmitters (Hampson et al. 2009, Páez et al. 2011).

Despite being fatal in $100 \%$ of cases, it can also be prevented in $100 \%$ of cases, either with massive pre-exposure vaccination or post-exposure prophylaxis measures, which include the use of immunoglobulins and vaccines, to prevent disease development in exposed patients (Abela-Ridder 2015, Cleaveland et al. 2006).

Countries that implement rabies elimination programs show a marked reduction in infections, often leading to the elimination of the disease (WHO 2013). To break the RABV transmission cycle, elimination programs center around dog vaccination campaigns, which must include at least $70 \%$ of the dog population in order to stop transmission (Belotto et al. 2005, Cleaveland et al. 2006, WHO 2013).

Of the 61,000 deaths per year caused by rabies in humans (WHO 2013), 99\% are caused by dog bites, proving the importance of rabies vaccination in dogs to prevent human rabies (Abela-Ridder 2015). In Colombia, seven cases of rabies transmitted by dogs and nine by cats have been officially reported since 1999 , showing that cats have acquired importance as a transmitter, due in large part to their nocturnal and hunting habits, that expose it to RABV by contact with wildlife rabies infected bats (Minsalud 2014, Castro Castro et al. 2016).

Colombia has historically been affected by urban and wildlife rabies outbreaks (Páez et al. 2003a, 2003b, 2005). The most recent outbreak of dog-transmitted rabies occurred in the years
2006-2008 in the Santa Marta Tourist District, Department of Magdalena, which claimed the lives of four humans and dozens of dogs (Páez et al. 2009a). Different case analyses show the ongoing occurrence of urban RABV outbreaks caused by wild variants and leading to multiple animal and human deaths in the country (Badillo et al. 2009, Mantilla et al. 2010, Páez et al. 2009b, Valderrama et al. 2006), and the increasing importance of cats as transmitter agents of these wild variants (Páez et al. 2009a, Castro Castro et al. 2016), which demonstrate the importance of maintaining high vaccination coverage also in cats, although the "Regional Program for the Elimination of Human Rabies" has been focused mainly on dogs (OPS 2005, Schneider et al. 2007).

To reduce rabies cases to zero, one essential point is to achieve sustained vaccination in dogs and cats. (Abela-Ridder 2015). In Colombia, canine and feline populations are increasing in urban areas; in Bucaramanga specifically, the estimated population of dogs and cats in 2010 was 39,582 individuals, of which 31,604 were canine and 7,978 feline (Arismendy et al. 2010), and although no clinical cases of canine rabies have been identified in the department of Santander since 2004, the arrival of wildlife rabies to urban populations is a constant threat (Badillo et al. 2009, Páez et al. 2009b, Mantilla et al. 2010).

In Colombia, the vaccination of canines and felines is mandatory. The national rabies vaccination program has achieved a national vaccination coverage that varied between 45\% and 63\% from 1994 to 2005 (Cediel et al. 2010). However, campaigns often do not have the expected impact because of multiple factors, including the dispersal of the vaccination strategy over the 12 months of the year and a likely underestimation of the canine population (OPS 2005), as well as the use of inactivated low potency vaccines, the number of doses, interval between vaccinations, age at vaccination, among others, all factors that can influence the immune response (Berndtsson et al. 2011). The impact of failures in the cold chain of vaccines, inadequate handling of biologicals, inappropriate vaccine inoculation in canines, use of expired vaccines, or dishonesty of the persons or entities that sell the vaccines (Paéz et al.2007) has also been described. In Colombia, these problems have led to vaccine failures in which up to $35 \%$ of the vaccinated population does not develop an immune response or does so inadequately (Páez et al. 2011).

The aim of the present study was to evaluate the production of neutralizing antibodies in dogs and cats vaccinated during the mass vaccination campaign of the second half of 2015 in the city of Bucaramanga and its metropolitan area. These data should be used to study the outcome of mass vaccination campaigns and as a tool for decision-making about the implementation of control strategies to improve vaccination coverage by health authorities, at both the regional and national levels.

\section{MATERIALS AND METHODS}

Ethics statement. This study was approved by the Ethics Committee for Animal Experimentation of the Cooperative University of Colombia, Bucaramanga (Act 023 of July 2014). The owners and managers of the animal shelters signed an informed consent form endorsed by the above-mentioned ethics committee. In addition, the authors state that all scientific, technical, and administrative rules for animal research were followed on this study. 
Type of study and samples. A descriptive cross-sectional study with convenience sampling was conducted in 382 dogs and cats (295 dogs, 87 cats) belonging to the metropolitan area of Bucaramanga (Santander), Colombia (Fig.1). The sample size was defined using WinEpi 2.0 software (available online at: http://www.winepi.net/), considering an estimated prevalence of $50 \%$ and a $95 \%$ confidence level and assuming an error of $5 \%$. Taking into account pet ownership data, a ratio of 3:1 dogs to cats was sampled. The inclusion criterion for the patients was to have been vaccinated in a mass vaccination campaign and to have the card showing a vaccination date of no more than 10 months prior to the time of sampling.

In these patients, $1 \mathrm{ml}$ of blood was drawn into Vacutainer ${ }^{\circledR}$ tubes by puncturing the radial vein of the forearm or the cephalic vein (in dogs) or the jugular vein (in cats) using a 22 gauge needle. Samples were allowed to clot at room temperature and then centrifuged for 15 minutes at 5,000xg. Sera were separated and stored frozen at $-80^{\circ} \mathrm{C}$ until the levels of neutralizing anti-rabies antibodies were measured.

ELISA screening of the samples. To evaluate the humoral response of the animals, the quantitative Enzyme-Linked Immunosorbent Assay (ELISA) "Platelia Rabies II Kit ad usum Veterinarium" (Bio-Rad ${ }^{\circledR}$ Laboratories-Marnes La Coquette, France) was used for the detection and quantification of anti-rabies glycoprotein antibodies in the serum of animals, following the methodology and precautions recommended by the manufacturer.

This ELISA allows the quantification of equivalent neutralizing antibody titers $(\mathrm{EU} / \mathrm{ml})$ by comparison with a calibration curve prepared with different dilutions of an OIE-approved International Standard Serum with neutralizing antibody titers measured in IU/ml. This ELISA has been previously validated, with viral neutralization tests (Servat et al. 2007) showing optimal results.

In order to increase sensitivity the Platelia Rabies II kit, we used a threshold of $0.3 \mathrm{EU} / \mathrm{mL}$ instead of $0.5 \mathrm{EU} / \mathrm{mL}$ as has been reported recently (Knoop et al. 2010, Wasniewski et al. 2014). Neutralizing antibody titers are presented in four international standard categories: undetectable titers at a level of $<0.125 \mathrm{EU} / \mathrm{ml}$, insufficient titers at 0.125-0.3 EU/ml, sufficient titers at 0.3-4 EU/ml, and high titers at $>4 \mathrm{EU} / \mathrm{ml}$. According to this modification, Sensitivity and Specificity for this test has been reported of 92.68 and $100 \%$ respectively (Wasniewski et al. 2014).

Statistical analysis. The computer programs WinEpi 2.0 (available online at: http://www.winepi.net/) and Prism ${ }^{\circledR} 7.01$ for Windows $^{\mathrm{TM}}$ (GraphPad Software, La Jolla/CA) were used for the statistical analysis and processing of data. Descriptive statistics of demographic data were generated. Categorical variables are summarized as frequencies and proportions, and continuous variables are summarized as means or medians with their dispersion measures. A bivariate analysis was performed to compare the positive and negative results of the vaccinated patients using the chi-square test or Fisher's exact test. Normality was verified by the Shapiro-Wilk test, and the differences between continuous variables were calculated with the Mann-Whitney test. Comparisons among the animal shelters were performed using the Kruskal-Wallis test with Dunn's multiple comparisons test. In all cases, the results were considered statistically significant at a level of $p<0.05$.

\section{RESULTS}

The study population consisted of 295 dogs and 87 cats belonging to animal shelters in the city of Bucaramanga and its metropolitan area (Fig.1). These animals were vaccinated with one dose of inactivated rabies vaccine between 5 and 8 months prior to sampling. The population of dogs studied consisted of $37.28 \%$ males and $62.72 \%$ females. A similar sex distribution was found in the cat population, in which $39.08 \%$ were males and $60.92 \%$ females. The mean age was 3.69 years for the dogs (range 1 to 8 years) and 3.81 for the cats (range 1 to 10 years) included in the study.

In the evaluation of neutralizing antibodies, most of the animals did not have an adequate response to the vaccination, or seroconversion was not detected on them (65.45\%-95\% confidence interval, $\mathrm{CI}=60.68-70.21 \%$ ). To perform an optimal estimated of the antibody titers, we adjusted the prevalence according to the sensitivity and specificity data reported for the Platelia Rabies II ELISA (Wasniewski et al. 2014). The real prevalence of optimal neutralizing antibodies $(\geq 0.3 \mathrm{EU} / \mathrm{mL})$ was only $32.76 \%(95 \% \mathrm{CI}=28.05-37.46 \%)$ in the entire

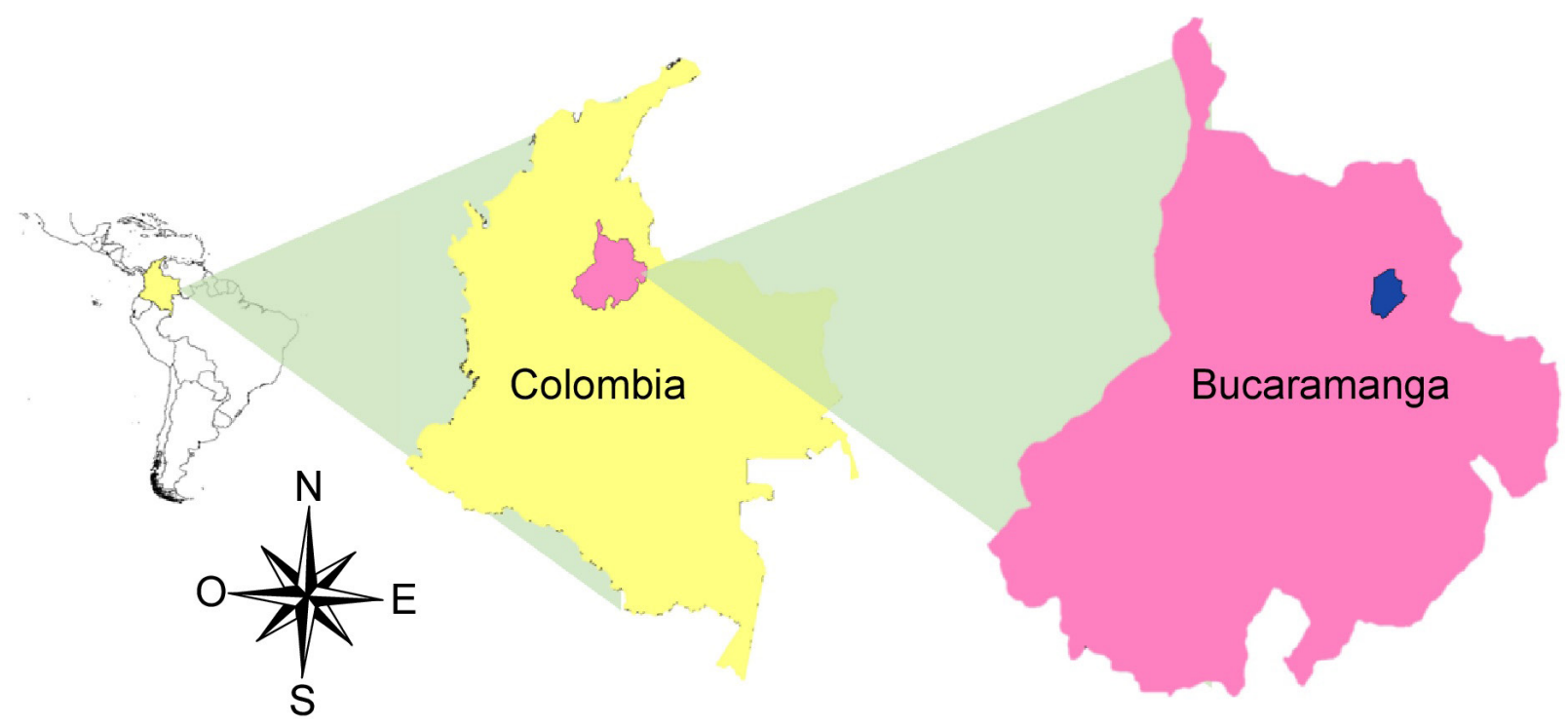

Fig.1. Geographical location of the sampling site in Bucaramanga, Colombia. The pink area denotes Santander Province, and the blue area denotes Bucaramanga City. The map was created using DIVA-GIS software version 7.5.0 for Windows ${ }^{\mathrm{TM}}$. 
population studied. In addition, the prevalence of suboptimal or insufficient antibodies was 4.51\% (95\% CI=2.43-6.59\%).

In the differential evaluation of neutralizing antibodies between dogs and cats, a highly significant difference $(p<0.001)$ was found between the neutralizing antibody titers in cats and dogs when titers were measured in Equivalent Units $/ \mathrm{ml}$ $(\mathrm{EU} / \mathrm{ml})$, with a higher neutralizing response shown in cats compared to dogs (Fig.2). Conversely, dogs had a statistically higher prevalence of non-reactors than cats (Fig.2A).

In the dog population, $26.69 \%(95 \% \mathrm{CI}=21.64-31.74 \%)$ of the dogs sampled had a sufficient neutralizing serological response (between 0.3 and $4 \mathrm{EU} / \mathrm{ml}$, Fig.2B). The highest proportion (77.17\%-95\% CI= 72.38-81.96\%) did not showed serological evidence of seroconversion to vaccination and $4.01 \%$ (95\% CI=1.77-6.25\%) of the dogs studied had an insufficient seroconversion rate.

The distribution in cats varied considerably to the dogs, with a prevalence of cats with sufficient antibody titers $(52.08 \%$ - 95\% CI=41.59-62.58\%) similar to the proportion of cats in which seroconversion was not detected (48.36\% - 95\% $\mathrm{CI}=37.86-58.86 \%)$. Only $6.19 \%$ (95\% CI=1.13-11.25\%) of the cats sampled had an insufficient neutralizing serological response. Of the entire population evaluated, only one individual (1.23\%-95\% CI=0.00-3.55\%) had a high level of neutralizing antibodies (>4 EU/ml, Fig. $2 \mathrm{~B}$ ).

In the analysis of antibody distribution by sex in dogs, significant differences were found between the neutralizing serological response of male dogs compared to the response of females (Fig.3A), with a higher frequency of male dogs that did not produce an immune response compared to females (Fig.3B). In the case of cats, no difference was found between
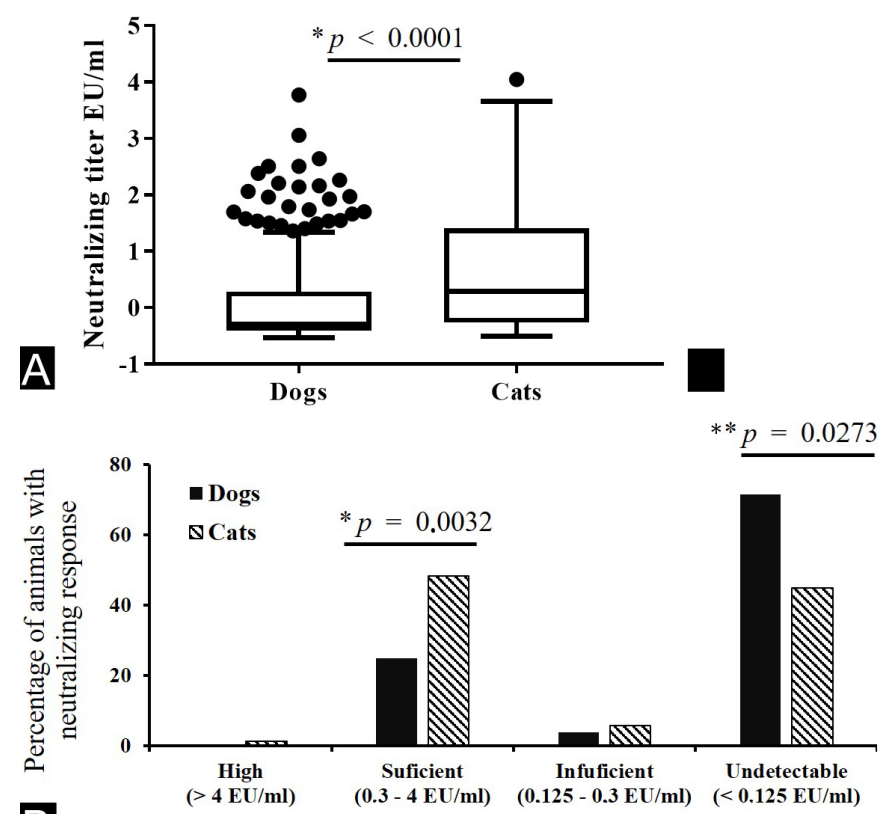

$\mathrm{B}$

Fig.2. Neutralizing antibodies after rabies vaccination in dogs and cats of Bucaramanga. (A) Distribution range according to OIE standards. (B) Tukey's box comparing the distribution of antibodies between dogs and cats. *Statistically significant Chi-square test $\left(\mathrm{X}^{2}\right),{ }^{* *}$ Statistically significant Mann-Whitney test. the antibody levels of males and females, nor was a difference observed in any of the seroconversion subgroups (Fig.3C,D)

Finally, to evaluate the occurrence of an anthropogenic effect in the vaccination process, a subgroup analysis was performed, evaluating 358 of the samples that belonged to the four main animal shelters. The assessment determined whether differences existed in the seroconversion level between the animals belonging to the different subgroups, with a highly significant difference being observed between them $(p<0.001)$, with better seroconversion rates in some shelters (Fig.4A,D) compared to others (Fig.4B,C). However, as shown in the figure, the majority of the population is distributed with a low level of neutralizing humoral immunity.

\section{DISCUSSION}

Although a reduction of more than $90 \%$ of the cases of human rabies transmitted by dogs in Latin America (OPS 2005, Schneider et al. 2007) has been achieved within the framework of the "Regional Program for the Elimination of Human Rabies Transmitted by Dogs", rabies is still considered the most important viral zoonosis (Dodet et al. 2008). In this endeavor, mass vaccination campaigns for dogs and cats are the most important measure to stop virus circulation among the animal population, and long-term sustained coverage is required to avoid the re-emergence of the disease (Schneider et al. 2007). In addition to good vaccination coverage, achievement of a good neutralizing immune response in the animals is necessary to demonstrate that vaccination has been successful, allowing the maintenance of the minimum levels of required population immunity (Hampson et al. 2009). Our results show that only a quarter of the population evaluated (25.92\%) achieved an optimal neutralizing immune response (Fig.2). This undoubtedly shows a failure in urban rabies elimination programs and a latent risk to the animal and human populations.

Although most of human rabies cases in Latin America have been transmitted by dogs (Schneider et al. 2007), in the last decade, cats have become a major bridge of transmission of wildlife rabies to humans (Páez et al. 2009a). In fact, the last case of human rabies in the region studied was due to a wild-type virus transmitted by cats in an urban area (Mejía-Angarita \& López-Martínez 2010), which shows the important impact that the inclusion of cats in the plans for control and elimination of rabies has on the epidemiology of the infection.

Notably, although $71.53 \%$ of the vaccinated dogs did not develop neutralizing humoral immunity, only $44.83 \%$ of the cats vaccinated in the mass vaccination campaigns of the second half of 2015 did not develop neutralizing antibodies. These results in dogs are far from the results reported by Paez et al (Páez et al. 2011), who demonstrated that 74.9\% of dogs had an adequate humoral immune response, that is, at levels equal to or higher than $0.5 \mathrm{IU} / \mathrm{ml}$. In the case of cats, the present study is the first one in Colombia that shows the results of the anti-rabies immune response in cats in the country.

In Bucaramanga, according to the data published by the Ministry of Health, rabies vaccination coverage in dogs and cats was $41.96 \%$ in 2014, (Minsalud 2015). When this coverage is added to the poor humoral response of vaccinated animals, a high risk level is shown for the re-emergence of both urban and wildlife rabies in animals and humans, as has already been reported (Mejía-Angarita \& López-Martínez 2010). 

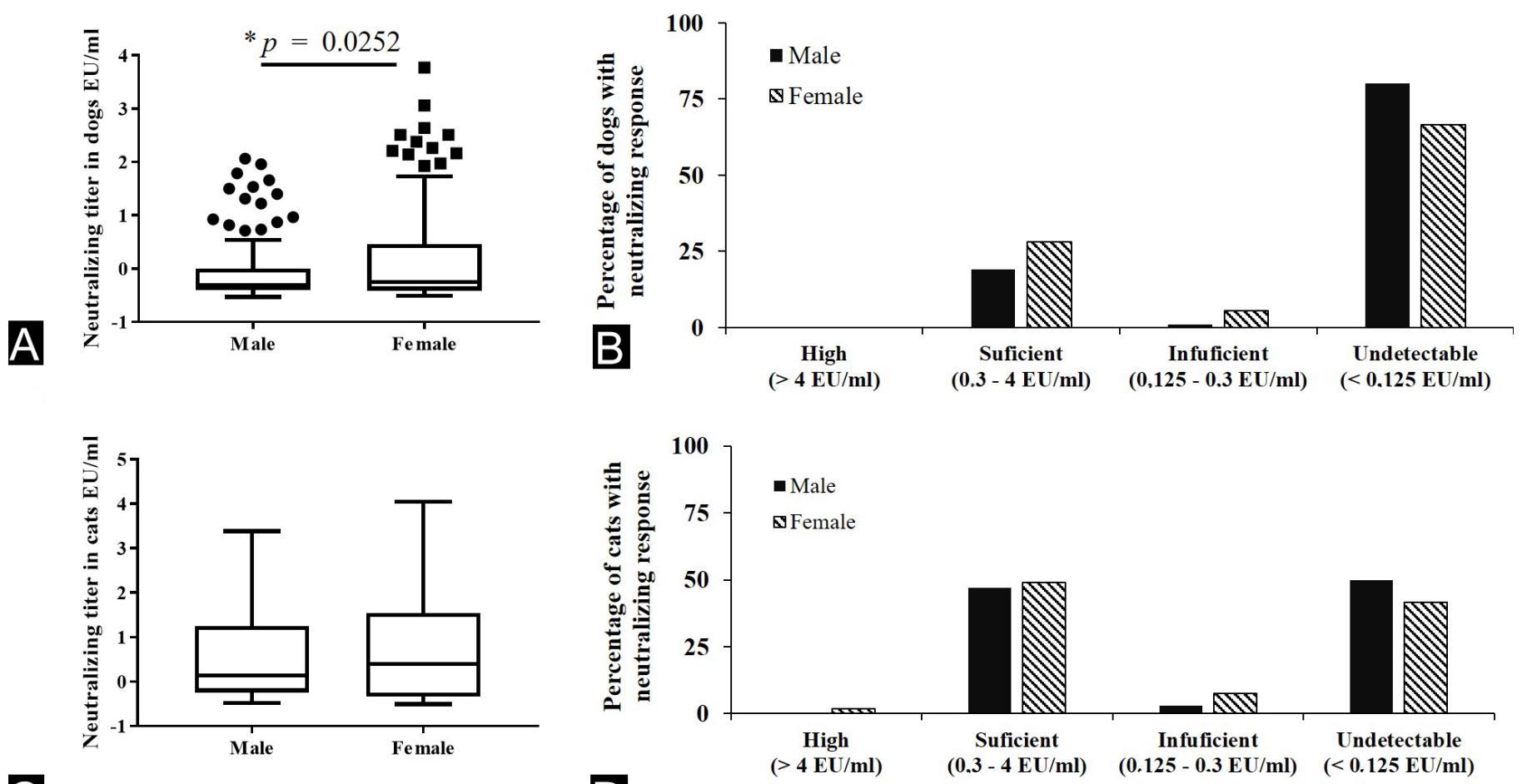

a

Fig.3. Sex distribution of rabies neutralizing antibodies after vaccination in dogs and cats Bucaramanga. (A) Tukey's box comparing the distribution of antibodies between male and female dogs. (B) Distribution range by sex according to OIE seroconversion standards in Dogs. (C) Tukey's box comparing the distribution of antibodies between male and female cats. (D) Distribution range by sex according to OIE seroconversion standards in cats. ${ }^{*}$ Statistically significant Chi-square test $\left(\mathrm{X}^{2}\right)$.

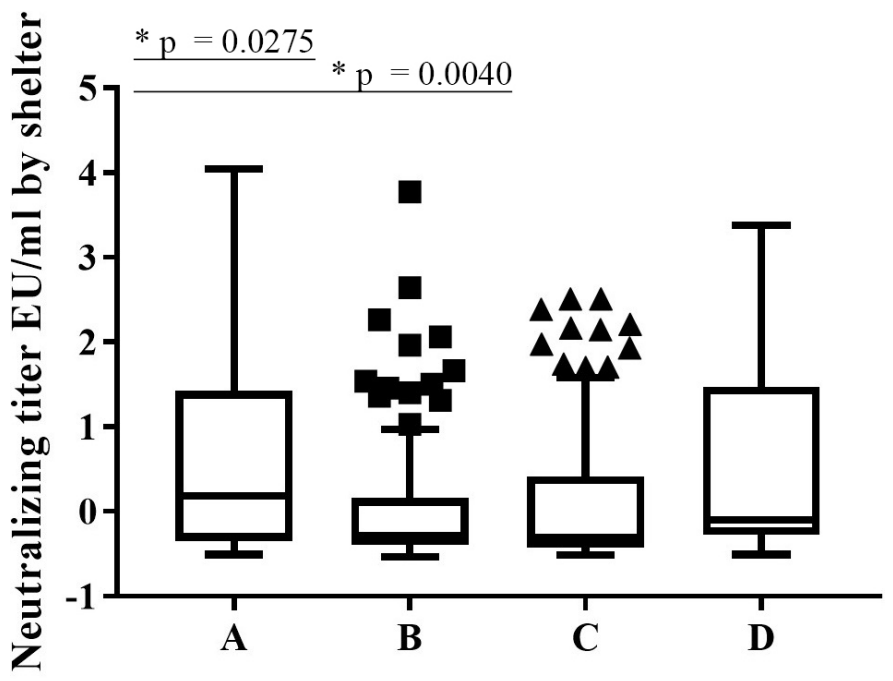

Animal Shelter

Fig.4. Distribution of neutralizing antibodies after anti-rabies vaccination in shelters. Tukey Box chart is presented comparing the distribution of neutralizing antibodies among the different shelters included in the study. *Statistically significant Kruskal-Wallis test with Dunn's multiple comparisons test.

Different factors might explain these low seroconversion rates. As an independent study, it was not possible to retrieve information from the manufacturer and/or type of vaccine used, batch, etc. However, although the vaccination card was reviewed (data not shown), the information provided in these cards by the personnel responsible for vaccinations was inconsistent and incomplete and did not allow the evaluation of vaccine-related variables that could explain the low rate of seroconversion. This information could be confirmed in the study by (Páez et al. 2011), demonstrating that there may be vaccines and/or batches that do not allow the production of effective antibody titers (Páez et al. 2011). The differences found in the level of seroconversion among animal shelters (Fig.4) allow us to assume that there are anthropogenic variables that influence the immune response of vaccinated animals. These occur in addition to the biological responses that affect the dogs and cats and are attributable to factors such as nutritional status or health status (Almeida et al. 1997, Rigo \& Honer 2006, Tordo et al. 2005).

Most of the regional campaigns of vaccination of dogs and cats against rabies in Brazil (Fernandes et al. 2017) and Colombia (present data) used cell culture rabies inactivated virus and aluminum hydroxide as adjuvant. Similar to the analyzed data by (Fernandes et al. 2017), Vaccine quality, dose, age of primary vaccination, nutritional status, presence of concomitant infections, in addition to the individual immunological capacity could not be evaluated, it is not possible to attribute to any of them the observed unresponsiveness to vaccination in many animals.

We believe that the number of vaccine doses received by the animals is not confusing the results. Although it has been reported that around $14 \%$ of primo-vaccinated dogs 
have presented neutralizing titers lower than the minimum threshold (0.5 IU/mL) (Cliquet et al. 2003), most of the animals belonging to the evaluated shelters has been previously vaccinated at least one time because vaccination at admittance of the shelter it is mandatory (Day et al. 2016) and it is well assumed that for multiple vaccinated dogs, antibody titers did not depend on the time elapsed since the last vaccination (Cliquet et al. 2003, Mansfield et al. 2004).

Also, it was previously demonstrated that the peak of rabies antibody titers initially rises and then from about 6 to 8 weeks onwards the titers slowly decreases, eventually resulting in an increase in the number of test failures (Jakel et al. 2008, Kennedy et al. 2007, Van de Zande et al. 2009). It could be possible that our evaluation lost the peak of seroconversion in the animals and that the level of antibodies goes below the protective threshold of $0.5 \mathrm{IU} / \mathrm{mL}$, however this does not mean that they are not protected against rabies (Lakshmanan et al. 2006); in fact, the presence of detectable neutralizing antibodies against rabies at the time of a possible wild type virus challenge does not indicate protection for all animals (Aubert 1992, Hooper et al. 1998).

This is the first study evaluating the vaccine response that includes samples of both dogs and cats in Colombia. Considerably, our results (Fig.2A) demonstrate a significant difference with a higher prevalence of neutralizing antibodies in vaccinated cats compared to dogs. Similarly, in a study of samples of dogs and cats vaccinated in two cities in Southeastern Brazil, significant differences were found in the development of antibodies between dogs and cats in only one of the cities studied (Albas et al. 2013). This finding could explain that the differential response of dogs and cats is mainly mediated by anthropogenic factors such as the vaccination culture and the quality of the vaccination, etc., rather than by a differential biological response between the two species (Moore et al. 2015, Tordo et al. 2005).

In similar way to our results, it has been recently reported the frequency and magnitude of neutralizing antibodies to RABV in dogs with and without historic of vaccination in Santa Maria/RS, Brazil, during missive 2015 rabies vaccination campaign (Fernandes et al. 2017), the results shown that after single dose vaccination, between $30-58 \%$ of dogs do not contain neutralizing antibodies against RABV in adequate levels, highlighting current vaccine status in dogs that may not be sufficient to prevent an eventual introduction and transmission of the virus to unprotected dogs (Fernandes et al. 2017).

Since the development of the Platelia ${ }^{\text {TM }}$ Rabies II kit ad usum Veterinarium by Bio-Rad in 2006 (Servat et al. 2007) and the certification by the OIE in 2007 for the determination of immune status postvaccination in individual dogs or cats (World Organisation for Animal Health 2007), this ELISA seemed to be a reliable alternative method to the current seroneutralisation tests (FAVN test: fluorescent antibody virus neutralisation test; RFFIT: rapid fluorescent focus inhibition test). However, many discordant results were observed when comparing the titers obtained by the Platelia Rabies II kit and those obtained with the FAVN or RFFIT. Compared to the FAVN test, this ELISA was not sensitive enough for rabies antibody detection with the current threshold of $0.5 \mathrm{EU} / \mathrm{mL}$ indicating that that this ELISA underestimates the rabies antibody titers obtained in vaccinated animals (even in high positive samples) compared to the gold standard tests (Knoop et al. 2010, Wasniewski et al. 2014).

In order to increase sensitivity of the Platelia Rabies II kit, results obtained from an international collaborative study of the proficiency of the test has shown that this ELISA could be used for research purposes with a threshold set at $0.3 \mathrm{EU} / \mathrm{mL}$ instead of $0.5 \mathrm{EU} / \mathrm{mL}$ (Wasniewski et al. 2014), recommendation that where take into account in this paper in order to have a more precise and less restrictive results.

As mention before, there is not outbreaks of urban rabies in Colombia since 2008 (Páez et al. 2009b); However multiple cases human rabies transmitted by cat or by bats has been recorded in urban areas (Valderrama et al. 2006, Páez et al. 2009a, Mantilla et al. 2010, Mejía-Angarita \& López-Martínez 2010). Besides, we have recently showed that Livestock rabies transmitted by bats has an increasing trend of the disease and is present in $62.5 \%$ of Colombian provinces (Marin-Alvarez et al. 2014). Thus, considering the potential risk of introduction of the virus from nearby rural areas through bat or cat hunting bats, our present data indicated that the vaccine coverage in dogs/cat could be unable to respond efficiently to a possible challenge with field virus and could lead to possible outbreak of urban canine/feline rabies and possibility to human rabies cases.

\section{CONCLUSIONS}

Our results highlight the low real coverage of rabies vaccination and demonstrate that, after a mass vaccination campaign, the vast majority of animals in the study population would be unable to respond efficiently to a challenge with field virus.

A post-vaccination determination of antibody titers is recommended as a more objective measure to evaluate rabies vaccination campaigns in addition to traditional coverage measures.

These results will allow the implementation of corrective measures in the Bucaramanga dog and cat population to achieve better seroconversion rates.

Other cities are expected to implement similar seroconversion assessments to prove the quality of effective anti-rabies vaccination in animal populations.

Competing interests. The authors declare that they have no competing interests.

Acknowledgements.- The authors wish to thank to the veterinarians Leidy Johanna Larrotta Suarez and Duly Rojas Gualdron for their help in sampling animals. Additionally, the authors thank the owners and animal shelters that agreed to participated in the study. This work was financially supported by CONADI-Universidad Cooperativa de Colombia Grant-V10. The funders had no role in the study design, data collection and analysis, decision to publish, or preparation of the manuscript.

\section{REFERENCES}

Abela-Ridder B. 2015. Rabies: 100 per cent fatal, 100 per cent preventable. Vet. Rec. 177 (6):148-149. <http://dx.doi.org/10.1136/vr.h4196> <PMid:26251539>

Afonso C.L., Amarasinghe G.K., Bányai K., Bào Y., Basler C.F., Bavari S., Bejerman N., Blasdell K.R., Briand F.-X., Briese T., Bukreyev A., Calisher C.H., Chandran K., Chéng J., Clawson A.N., Collins P.L., Dietzgen R.G., Dolnik O., Domier L.L., Dürrwald R., Dye J.M., Easton A.J., Ebihara H., Farkas S.L., Freitas-Astúa J., 
Formenty P., Fouchier R.A., Fù Y., Ghedin E., Goodin M.M., Hewson R., Horie M., Hyndman T.H., Jiāng D., Kitajima E.W., Kobinger G.P., Kondo H., Kurath G., Lamb R.A., Lenardon S., Leroy E.M., Li C.X., Lin X.D., Liú L., Longdon B., Marton S., Maisner A., Mühlberger E., Netesov S.V., Nowotny N., Patterson J.L., Payne S.L., Paweska J.T., Randall R.E., Rima B.K., Rota P., Rubbenstroth D., Schwemmle M., Shi M., Smither S.J., Stenglein M.D., Stone D.M., Takada A., Terregino C., Tesh R.B., Tian J.H., Tomonaga K., Tordo N., Towner J.S., Vasilakis N., Verbeek M., Volchkov V.E., Wahl-Jensen V., Walsh J.A., Walker P.J., Wang D., Wang L.F., Wetzel T., Whitfield A.E., Xiè J.T., Yuen K.Y., Zhang Y.Z. \& Kuhn J.H. 2016. Taxonomy of the order Mononegavirales: update 2016. Arch. Virol. 161(8):2351-2360.<http://dx.doi.org/10.1007/s00705016-2880-1><PMid:27216929>

Albas A., Picolo M.R., Soares C.N., Bachega H.V.U. \& Tarumoto M.H. 2013. Humoral immune response in dogs and cats vaccinated against rabies in southeastern Brazil. J. Venom. Anim. Toxins incl. Trop. Dis. 19(1):17. <http://dx.doi.org/10.1186/1678-9199-19-17><PMid:23899101>

Almeida M.F., Aguiar E.A., Martorelli L.A., Presotto D., Brandão M.M. \& Pereira 0.A. 1997. Resposta imune humoral de cães à vacina inativada, de cérebro de camundongos lactentes, utilizada nas campanhas anti-rábicas no Brasil. Revta Saúde Públ. 31(5):502-507.<http://dx.doi.org/10.1590/ S0034-89101997000600009>

Arismendy A., García A., Gonzales C., Pinzón C., Delgado E. \& Flóres F. 2010. Primer censo canino, felino del área urbana del municipio de Bucaramanga. Universidad Cooperativa de Colombia, Facultad de Medicina Veterinaria y Zootecnia. 130p.

Aubert M.F. 1992. Practical significance of rabies antibodies in cats and dogs. Rev.Sci. Tech. 11(3):735-760.<http://dx.doi.org/10.20506/rst.11.3.622> $<$ PMid:1472723>

Badillo R., Mantilla J.C. \& Pradilla G. 2009. Encefalitis rábica humana por mordedura de murciélago en un área urbana de Colombia. Biomédica 29(2):191-203. <http://dx.doi.org/10.7705/biomedica.v29i2.21> $<$ PMid:20128344>

Belotto A., Leanes L., Schneider M., Tamayo H. \& Correa E. 2005. Overview of rabies in the Americas. Virus Res. 111(1):5-12.<http://dx.doi.org/10.1016/j. virusres.2005.03.006><PMid:15896398>

Berndtsson L.T., Nyman A.-K.J., Rivera E. \& Klingeborn B. 2011. Factors associated with the success of rabies vaccination of dogs in Sweden. Acta Vet. Scand. 53(1):22. <http://dx.doi.org/10.1186/1751-0147-53-22> <PMid:21439029>

Bourhy H., Reynes J.-M., Dunham E.J., Dacheux L., Larrous F., Huong V.T.Q., Xu G., Yan J., Miranda M.E.G. \& Holmes E.C. 2008. The origin and phylogeography of dog rabies virus. J. Gen. Virol. 89(Pt 11):2673-2681. <http://dx.doi. org/10.1099/vir.0.2008/003913-0><PMid:18931062>

Castro Castro F.F., Rodríguez M. \& Patricia M. 2016. Feline rabies in a domestic cat (Felis silvestris catus), Yumbo, Valle Del Cauca, Colombia. Revta UDCA Actual. Divers. Cient. 19:243-246.

Cediel N., De la Hoz F., Villamil L.C., Romero J. \& Díaz A. 2010. Epidemiología de la rabia canina en Colombia. Revta Salud Publica 12(3):368-379. <http:// dx.doi.org/10.1590/S0124-00642010000300003> <PMid:21311825>

Cleaveland S., Kaare M., Knobel D. \& Laurenson M.K. 2006. Canine vaccination: providing broader benefits for disease control. Vet. Microbiol. 117(1):4350. <http://dx.doi.org/10.1016/j.vetmic.2006.04.009><PMid:16701966>

Cliquet F., Verdier Y., Sagne L., Aubert M., Schereffer J.L., Selve M., Wasniewski M. \& Servat A. 2003. Neutralising antibody titration in 25,000 sera of dogs and cats vaccinated against rabies in France, in the framework of the new regulations that offer an alternative to quarantine. Rev. Sci. Tech. 22(3):857866. <http://dx.doi.org/10.20506/rst.22.3.1437><PMid:15005543>

Day M.J., Horzinek M.C., Schultz R.D. \& Squires R.A. 2016. WSAVA Guidelines for the vaccination of dogs and cats. J. Small Anim. Pract. 57(1):E1-E45. <http://dx.doi.org/10.1111/jsap.2_12431> <PMid:26780857>
Dodet B., Fooks A.R., Müller T. \& Tordo N. 2008. Towards the elimination of rabies in Eurasia. Proc. Joint OIE/WHO/EU International Conference. Develop. Biol., Basel 131:3-584.

Fernandes K.G., Martins M., Amaral B.P., Cargnelutti J.F., Weiblen R. \& Flores E.F. 2017. Antibodies against rabies virus in dogs with and without history of vaccination in Santa Maria/RS, Brazil. Ciência Rural 47(11): e20170125. <http://dx.doi.org/10.1590/0103-8478cr20170125>

Hampson K., Dushoff J., Cleaveland S., Haydon D.T., Kaare M., Packer C. \& Dobson A. 2009. Transmission dynamics and prospects for the elimination of canine rabies. PLoS Biol 7(3):e1000053. <http://dx.doi.org/10.1371/ journal.pbio.1000053><PMid:19278295>

Hooper D.C., Morimoto K., Bette M., Weihe E., Koprowski H. \& Dietzschold B. 1998. Collaboration of antibody and inflammation in clearance of rabies virus from the central nervous system. J. Virol. 72(5):3711-3719. $<$ PMid:9557653>

Jakel V., Konig M., Cussler K., Hanschmann K. \& Thiel H.J. 2008. Factors influencing the antibody response to vaccination against rabies. Develop. Biol., Basel 131:431-437. <PMid:18634505>

Kennedy L.J., Lunt M., Barnes A., McElhinney L., Fooks A.R., Baxter D.N. \& Ollier W.E. 2007. Factors influencing the antibody response of dogs vaccinated against rabies. Vaccine 25(51):8500-8507. <http://dx.doi.org/10.1016/j. vaccine.2007.10.015><PMid:18006120>

Knoop E.V., Freuling C.M., Kliemt J., Selhorst T., Conraths F.J. \& Muller T. 2010. Evaluation of a commercial rabies ELISA as a replacement for serum neutralization assays as part of the pet travel scheme and oral vaccination campaigns of foxes. Berl. Munch. Tierarztl. Wochenschr. 123(7-8):278-285. <PMid:20690539>

Lakshmanan N., Gore T.C., Duncan K.L., Coyne M.J., Lum M.A. \& Sterner F.J. 2006. Three-year rabies duration of immunity in dogs following vaccination with a core combination vaccine against canine distemper virus, canine adenovirus type-1, canine parvovirus, and rabies virus. Vet. Ther. 7(3):223231. <PMid:17039445>

Mansfield K.L., Burr P.D., Snodgrass D.R., Sayers R. \& Fooks A.R. 2004. Factors affecting the serological response of dogs and cats to rabies vaccination. Vet. Rec. 154(14):423-426. <http://dx.doi.org/10.1136/vr.154.14.423> <PMid:15119893>

Mantilla J.C., Sierra J.C., García E. \& Pradilla G. 2010. Forma paralitica de un caso de rabia humana trasmitida por murciélago, simulando Síndrome de Guillain Barre: presentación de un caso de autopsia. Revta Univ. Industr. Santander, Salud 42:139-151.

Marin-Alvarez L.M., Ruíz Buitrago J.D. \& Ruiz-Saenz J. 2014. Analysis of a program for the prevention and control of wild rabies and its role in the number of cattle outbreaks during years 2001 to 2011. Revta CES Med. Zootec. 9:203-217.

Mejía-Angarita J. \& López-Martínez L. 2010. Reporte de casos de rabia humana, Santander, 2008-2010. Informe Epidemiológico de Santander 4:1-12.

Minsalud 2014. Colombia Completa siete años sin casos de rabia humana transmitida por perro. Boletín de Prensa No 274 de 2014, Social MdSyP, Ministerio de Salud y Proteccion Social, Colombia. Available at <https:// www.minsalud.gov.co/Paginas/Colombia-completa-siete-a\%C3\%B1ossin-casos-de-rabia-humana-transmitida-por-perro.aspx> Accessed on Jul. 19, 2018.

Minsalud 2015. Cobertura municipal de vacunación antirrábica de perros y gatos 2014. Ministerio de Salud y Proteccion Social, Colombia.

Moore M.C., Davis R.D., Kang Q., Vahl C.I., Wallace R.M., Hanlon C.A. \& Mosier D.A. 2015. Comparison of anamnestic responses to rabies vaccination in dogs and cats with current and out-of-date vaccination status. J. Am. Vet. Med. Assoc. 246(2):205-211.<http://dx.doi.org/10.2460/javma.246.2.205> $<$ PMid:25554936> 
OPS 2005. Eliminación de la Rabia Humana Transmitida por Perros en América Latina: análisis de la situación. Organización Panamericana de la Salud, Washington, D.C. 73p.

Páez A., Nuñez C., García C. \& Boshell J. 2003a. Molecular epidemiology of rabies epizootics in Colombia, 1994-2002: evidence of human and canine rabies associated with chiroptera. Biomédica 23(1):19-30. <http://dx.doi. org/10.7705/biomedica.v23i1.1194> <PMid:12696396>

Páez A., Nũñez C., García C. \& Bóshell J. 2003b. Molecular epidemiology of rabies epizootics in Colombia: evidence for human and dog rabies associated with bats. J. Gen. Virol. 84(Pt 4):795-802. <http://dx.doi.org/10.1099/ vir.0.18899-0> <PMid:12655080>

Páez A., Saad C., Núñez C. \& Boshell J. 2005. Molecular epidemiology of rabies in northern Colombia 1994-2003. Evidence for human and fox rabies associated with dogs. Epidemiol. Infect. 133(3):529-536. <http://dx.doi. org/10.1017/S0950268805003699><PMid:15962560>

Paéz A., Gómez J., Calvo P. \& Garzón P. 2007. Niveles de inmunidad humoral conferidos con la primera dosis de la vacuna antirrábica en caninos con dueño de la ciudad de Bogotá, Colombia. Revta Invest 7:191-197.

Páez A., Hernández C., Escobar H., Zapata J.J., Méndez J. \& Rey-Benito G. 2011. Evaluaciôn de la seroconversion como respuesta a la vacunaciôn antirrabica en perros en el departamento del Valle del Cauca, Colombia, 2009. Biomédica 31(4):474-484.<http://dx.doi.org/10.7705/biomedica. v31i4.395><PMid:22674358>

Páez A., Rey G., Agudelo C., Dulce A., Parra E., Díaz-Granados H., Heredia D. \& Polo L. 2009a. Brote de rabia urbana transmitida por perros en el distrito de Santa Marta, Colombia, 2006-2008. Biomédica 29(3):424-436. <http:// dx.doi.org/10.7705/biomedica.v29i3.14> <PMid:20436994>

Páez A., Polo L., Heredia D., Nuñez C., Rodriguez M., Agudelo C., Parra E., Paredes A., Moreno T. \& Rey G. 2009b. Brote de rabia humana transmitida por gato en el municipio de Santander de Quilichao, Colombia, 2008. Revta Salud Publica 11(6):931-943.<http://dx.doi.org/10.1590/S0124$00642009000600009><$ PMid:20379666>

Rigo L. \& Honer M.R. 2006. Titulação de anticorpos contra o vírus da raiva em cães, em Campo Grande/MS, na Campanha anti-rábica de 2003. Revta
Soc. Bras. Med. Trop. 39(6):553-555. <http://dx.doi.org/10.1590/S003786822006000600008>

Schneider M.C., Belotto A., Adé M.P., Hendrickx S., Leanes L.F., Rodrigues M.J.F., Medina G. \& Correa E. 2007. Current status of human rabies transmitted by dogs in Latin America. Cad. Saúde Pública 23(9):2049-2063. <http:// dx.doi.org/10.1590/S0102-311X2007000900013><PMid:17700940>

Servat A., Feyssaguet M., Blanchard I., Morize J.L., Schereffer J.L., Boue F. \& Cliquet F. 2007. A quantitative indirect ELISA to monitor the effectiveness of rabies vaccination in domestic and wild carnivores. J. Immunol. Methods 318(1-2):1-10. <http://dx.doi.org/10.1016/j.jim.2006.07.026> <PMid:17166510>

Tordo N., Bahloul C., Jacob Y., Jallet C., Perrin P. \& Badrane H. 2005. Rabies: epidemiological tendencies and control tools. Develop. Biol., Basel 125:313. <PMid:16878455>

Valderrama J., García I., Figueroa G., Rico E., Sanabria J., Rocha N., Parra E., Saad C. \& Páez A. 2006. Brotes de rabia humana transmitida por vampiros en los municipios de Bajo y Alto Baudó, departamento del Chocó, Colombia 2004-2005. Biomédica 26(3):387-396. <http://dx.doi.org/10.7705/ biomedica.v26i3.357><PMid:17176002>

Van de Zande S., Kaashoek M., Hesselink W., Sutton D. \& Nell T. 2009. Comments to "Comparison of antibody responses after vaccination with two inactivated rabies vaccines" [Minke J.M. et al. 2009. Vet. Microbiol. 133:283286]. Vet. Microbiol. 138(1/2):202-203. <http://dx.doi.org/10.1016/j. vetmic.2008.12.026> <PMid:19303227>

Wasniewski M., Labbe A., Tribout L., Rieder J., Labadie A., Schereffer J.L. \& Cliquet F. 2014. Evaluation of a rabies ELISA as an alternative method to seroneutralisation tests in the context of international trade of domestic carnivores. J. Virol. Methods 195:211-220. <http://dx.doi.org/10.1016/j. jviromet.2013.10.021><PMid:24161815>

WHO 2013. WHO Expert Consultation on Rabies: second report. World Health Organization. 150p.

World Organisation for Animal Health 2007. Resolution No. XXIX. Register of Diagnostic Tests Validated and Certified by the OIE World Organisation for Animal Health, Paris, France. 